\title{
Form variation of the rotifer Brachionus variabilis (Hempel, 1896) from the Orinoco River (Venezuela)
}

\author{
Ł. Vásquę1 \\ W. Koste?
}

Keywords: rotifer, Brachiontus variabilis, form variation, Orinoco River.

A description is made of a new form of Brachionus variabilis found in zooplankton samples collected in the Orinoco River. This is also the first record of this species in Venezuela.

Variation morphologlque du rotifère Brachionus variabilis (Hempel. 1896) dans l'Orénoque (Vénézuela).

Mots clés : rotifère, Brachionus variabilis, variation morphologique, Orénoque.

Une nouvelle forme de Brachionus variabilis trouvée dans le zooplancton de l'Orénoque est décrite. L'espèce est citée pour la première fois du Vénézuela.

\section{Introduction}

In a long term study of zooplankton from the Orinoco River and some floodplain lakes 116 rotifer taxa have so far been identified (Vásquez 1984) of which 36 species are new records for Venezuela. This group is an important element of the zooplankton in terms of abundance and species richness (Vásquezz 1984, Vásquez \& Sánchè 1984). Brachionus and Keratella represent two of the most important rotifer genera found in the Orinoca floodplain lakes. Samplings were done in the river at high water (September 1985) and low water (April 1986) to analyze longitudinal distribution of zooplankton in a river section of some $900 \mathrm{~km}$. Qualitative analysis of samples collected with a $45 \mu \mathrm{m}$ plankton net from the center and both margins of the river revealed the presence of a Brachionus variabilis form not previously described in the literature (/ig. 1-2). This is also the first record of this species for Venezuela. In South

\footnotetext{
1. Fundación La Salle de Ciencias Naturales, Estación Hidrobiológica de Guayana, Apdo. 51, San Félix, Edo. Bolívar, Venezuela 2. Ludwig-Brill-Strasse 5, D-4570, Quakenbrück, Federal Republic of Germany.
}

America, this species was first discovered in Peru : other records have been reported for the Pampa, Patagonian and Andean zoogeographical areas (Koste \& De Paggi 1982).

The purpose of this paper is to present a taxonomic description of this new form of $B$. variabilis.

\section{Taxonomic description}

Ruttner-Kolisko (1974) and Koste (1978) include B. variabilis within the urceolaris group. Form differentiation in this group is mainly based on foot opening shape, the shape of the ventral anterior margin of the lorica, sculpture and outline of the lorica. Ahlstrom (1940) presents a detailed description of the species indicating that \& This species may be readily recognized by the subquadrate plate projecting over the foot orifice ". B. variabilis from the Orinoco presents a smooth, flexible, and transparent lorica of heraldic outline without posterior spines and with short anterior spines. Median anterior spines are a little longer than the others. In dorsal view a quadrate plate projects over the foot opening and extends beyond the lorica ventrally covering the foot 


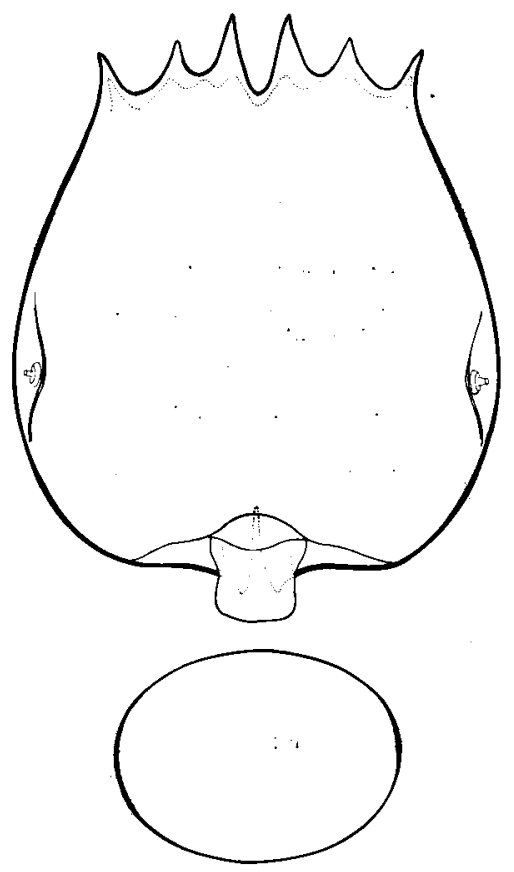

Fig. 1. B. vanabilis Dorsal lorica and subitaneous egg.

opening. The foot opening presents a large, narrow, inverse V-shaped aperture. Posteriorly the lorica widens. Dorso - ventral depth, at the base, about half of width. Lateral antennae are well developed.

Measurements $(\mu \mathrm{m})$ : lorica length : 217.270 ; lorica width : 170-190; foot-opening length : 15-20; Dorso-ventral length : 99-130.

\section{Discussion}

The most important morphological feature which assigns this new form to the type species as described by Ahlstrom (1940) is the presence of a subquadrate extension of the dorsal plate overhanging the foot opening. Similar extension, but triangular or rounded have been reported for different forms of $B$. candartus. The new form differs basically from the type species by the shape of the foot opening, by the wider caudal section and by a shorter ventral lorica. Even though a true basal plate is not present in the new form, in lateral view its caudal section resembles the basal plate of $B$. bidentata. This plate-like base is even more similar to that illustrated by Koste \& Shiel (1983) for B. urceolaris sericus f. africana.

In our case, this new form has only been observed in samples from the Orinoco River waters 

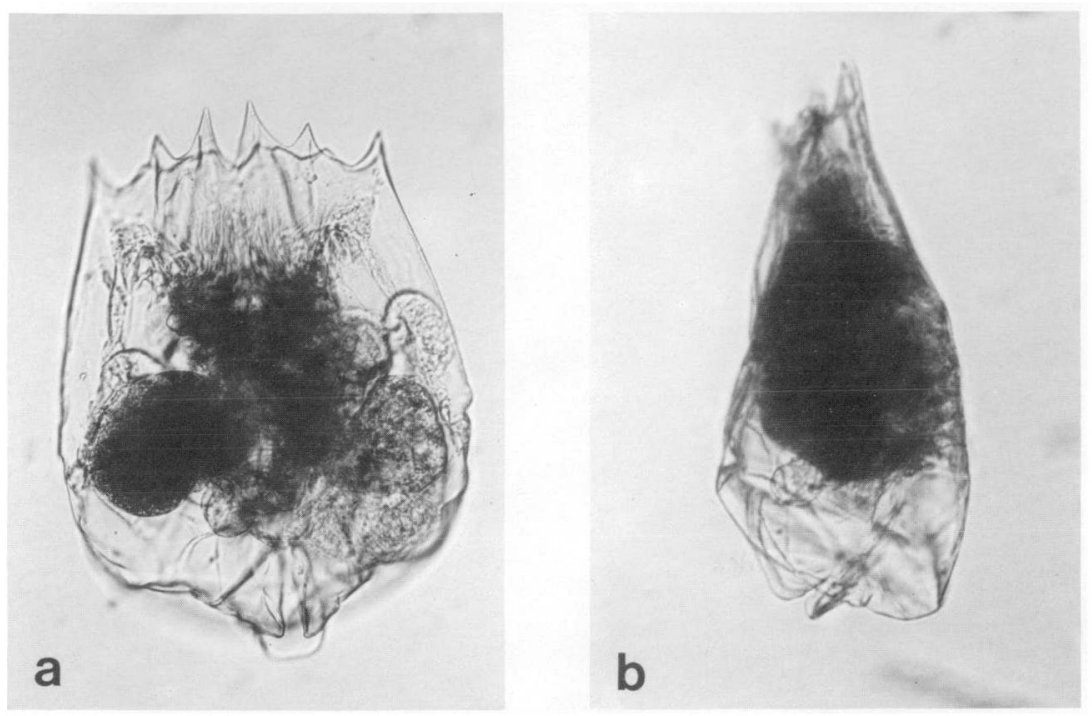

Fig. 2. B. tariabilis : a) Ventral lorica. b) Lateral view of lorica.

(average values for dates of collections : Temperalure : $28.3^{\circ} \mathrm{C} ; \mathrm{DO}: 6.5 ; \mathrm{pH}: 6.6 ;$ conductivity : 40 ${ }_{1} \mathrm{~s} \mathrm{~cm}^{-1}$ ). Some specimens were collected carrying eggs which suggests an ability for the species to develop in this lotic environment.

\section{References}

Ahlstrom (E.H.). 1940. - A revision of the rotatorian genera Bra. chionus and Platyias with descriptions of one new species and two new varieties. Am. Mus. Nat. Hist. 77(3): 148-184.

Koste (W.). 1978. - Die Rädertiere Mitteleuropas, Uberordnung Monogononta. Begründet von M. Voigt. I. Textbd. VIII +673 pp ; II. Tafelbd. 234 tables; Stuttgart.
Koste (W.) \& De Paggi (S.J.). 1982. - Rotifera ot the Superorder Munogonta recorded from Neotropis. Gewässer und Abwässer. $68 / 69: 71-102$.

Koste (W.) \& Shiel (R.J.). 1983. - Morphology. systematics and ecology of new monogonont Rotifera (Rotatoria) from the Alligator Rivers region. Northern Territory. Trans. R. Soc. S. Aust. $107(2): 109-121$.

Rut tner-Kolisko (A.). 1974. - Plankton rotifers, biology and taxonomy, Bimengew'üser 26(1) Suppl. : 1-146.

Vásquer (E.). 1984. - Estudio de las comunidades de rotíferos del Orinoco Medio, Bajo Caroní y algunas lagunas de inundación (Venezuela). Mem. Soc. Cienc. Nat. La Salle, 44(121): 95-108.

Vásquez (E.) \& Sanchez (L.). 1984. - Variación estacional del plancton en dos sectores del rio Orinoco y una alguna de inunda. ción adyacente. Mem. Soc. Cienc. Nai. La Salle, 44(121): $11-31$. 